\title{
Self-Designed Project Based Learning in the Lathe Machining Field
}

\author{
A. Hamdani, A Djohar, and D. Hidayat \\ Department of Mechanical Engineering Education, FPTK \\ Universitas Pendidikan Indonesia \\ Bandung, Indonesia \\ aam_hamdani@upi.edu
}

\author{
Wahyudin \\ Department of Mathematics Education, FMIPA \\ Universitas Pendidikan Indonesia \\ Bandung, Indonesia
}

\begin{abstract}
The problem in this research is the lack of direct experience of the atmosphere experienced by students in the industrial atmosphere that can enhance the students' competence in the field of machining. The purpose of this research is to find a model learning design which can provide industrial atmosphere in the school and can improve work skills in the field of machining, and find the model implementation. The research methodology used was a research and development ( $R \& D)$, which include 1) development of materials and instructional design that includes schools, industrial and Professional Certification Agency, 2) performed limited testing and extensive testing, 3) validation test of the products produced by conducting experiments in learning. The results showed that 1 ) the self designed learning model this project is an alternative learning which provide direct experience with industrial atmosphere in the school and is able to improve the skills demanded by industry. 2) This alternative learning more insightful works that include product planning, manufacturing work steps, cost planning and quality control of products and employment. 3) based on the results of the Independent Samples Test table noted that sig ( 2 tailed) of $0.000<\square=0.025$. This means that there is significant influence learning model material industry work towards integration competence competence of vocational students. Implications of this study are 1) Through this learning model, students can portray himself as a worker / operator and gain direct experience working atmosphere at school. And able to make grow the entrepreneurship spirit.2) implement this model is a challenge and to improve the professionalism of teachers, because in this model the teacher acting as supervisor as well as assessors. 3) implementation of this model can help develop learning and utilize the facilities, teacher resources and industrial relations in creating students who have industry competence.
\end{abstract}

Keywords - Competence, Self-Designed Project-based Learning, Reseach and Development.

\section{INTRODUCTION}

Secondary vocational education has a strategic role to prepare students to be ready to work both independently (selfemployed) and also fill job vacancies in the industrial world. It means to be a labor, must have the knowledge, skills and attitudes appropriate to the qualifications of graduates working world [1].To be able to work and compete in the industry as well as self-employment, vocational graduates should have the competence, capabilities which are required to complete a specific job in the world of work and the need official recognition of the capability [2].Learning programs in vocational schools is specifically directed learning programs so that graduates become capable worker or self-employed $s$ in the field.

Programs and learning at a vocational school is an applicative program [3], so that everything that is taught vocational schools are the things that allow students to survive through the skills acquired from education and the learning process. Ability in accordance with the work in the industrial world are grouped in the Indonesian National Work Qualification (SKKNI) while recognition of these competencies can be done by National Professional Certification Board (BNSP) through the stands is done by Professional Certification Institute (LSP).Related to the above, the dynamics target of development of vocational education provision directed to SMK able to play an active role in the economic growth and social welfare [4]. Clearly implied that through vocational education is expected to form a professional human productive, adaptive / creative and based on the value system, even meet the characteristics of Indonesia intelligent man, accompanied by a personality trait which refers to aspects of value system. Still large number of unemployed supplied by vocational graduates showed weaknesses in the education program at the vocational school [5]. While the level of quality and relevance that the amount of absorption of graduates and compliance areas of work with the chosen field of expertise and practiced difficult to achieve [4]. So that the quality of vocational graduates in accordance with the appropriate industry needs, of course, required a planning education and learning program where students are trained in an environment similar conditions the next time they work [3]. The introduction of the world of work is very important for prospective vocational graduates. Standards of competence-based learning can improve the competence of vocational students working in the field of machining [6].Besides that learning outcomes in line with the conditions of employment in the industrialized world, it is necessary to equip science through competency development model of industrial employment vocational students the machining area of expertise.

\section{RESEARCH METHODS}

Development of alternative models of learning is done by following the steps in the process of research and development (R \& D). Broadly speaking, the study grouped in three stages: 1) development of materials and instructional design that includes 
schools, industrial and Professional Certification Agency, 2) performed limited testing and extensive testing, 3) validation test of the products produced by conducting experiments in learning.

Instruments to be able to reveal the data on job skills include cognitive measurement instrument containing indicators for product planning. Instruments to measure job skills, are instruments issued by the National Education Standards Agency (BNSP). To reveal the students' opinions about the learning of this alternative is used questionnaires.

The samples used were vocational students Machining Engineering Program in the city of Bandung. Students sampled are students who have qualified in the mastery of basic machining.

\section{DISCUSSION}

Implementation assessment competency improvement is directed to measure and assess the performance of learners (aspects of knowledge, skills, and attitudes), either directly at the time of learning activities and indirectly, namely through evidence of learning outcomes in accordance with the performance criteria are organized in the form of portfolio. Learning concept which is designed must meet the elements of student competence excavations are able to meet industry job competence.

After testing and evaluating the implementation of the scheme Implemantasi learning model of self-design project is shown in Figure 1.

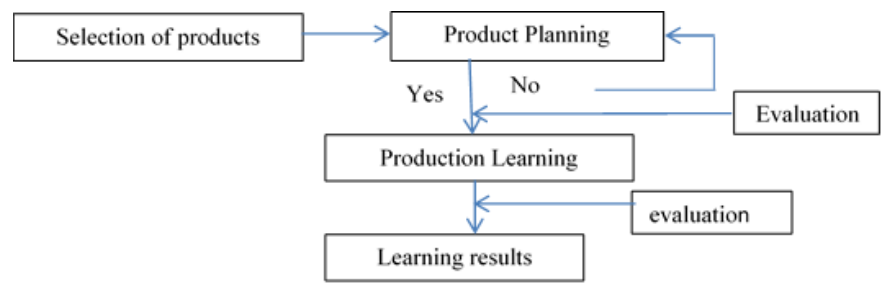

Fig. 1. Schematic of self-learning project design implementation

Under the scheme of implementation of the measures of this model may be disclosed results of the study are: 1) All students are able to plan products according to the indicators that have been set. 2) All the students were able to work on the process of making a product with an average value of 9.25. BNSP assessment based format, the value in the range (9.00 to 10.00), the students said to meet the qualification standards of the industry. 3) Based on the results of the Independent Samples Test table noted that sig ( 2 tailed) of $0.000<\square=0.025$. This means that there is significant influence learning model material industry work towards integration competence competence of vocational students. 4) The results of the comparison value in the process of validation test, it can be mentioned that the alternative learning model can improve job skills in the field of machining.
While based questionnaire students' opinions on the implementation of this model, 1) all students it states that learning is a new learning was first obtained, 2) almost all students found through alternative learning is more flexibility in exploring the science related to machining, well almost entirely stated liveliness participate in learning. In the case of extracting the potential of students, 3) almost entirely state that this study is to explore the potential students in both the planning of the product or manufacture of the product. For an insight into the development theme of work, 4) almost all of the students stated that this alternative learning more insightful works that include product planning, manufacturing work steps, cost planning and quality control of products and employment. To the theme of the development of self-confidence, 5) almost all of the students expressed through these alternative learning, can boost the confidence of employability and entrepreneurship in the field of machining.

\section{CONCLUSIONS}

- Based on the results of the Independent Samples Test table noted that $\operatorname{sig}$ ( 2 tailed) of $0.000<\square=0.025$. This means that there is significant influence learning model material industry work towards integration competence competence of vocational students

- based on independent table test samples, obtained that sig (2-tailed) $0.005<0.025$, which means it can be concluded that there are differences increase students' cognitive abilities after using Self designed project learning model

- Self designed project learning model more insightful works that include product planning, manufacturing work steps, cost planning and quality control of products and employment.

- Self designed project learning model, can increase the confidence of employability and entrepreneurship in the field of machining.

\section{REFERENCES}

[1] Stevenson John, 2003 Developing Vocational Expertise, Principles and issues in vocational education, Allen \& Unwin, CMO Image Printing Enterprise, Singapore.

[2] Bukit Masriam (2002), Beberapa Masalah dalam Implementasi Pendidikan Sistem Ganda di SMK, Sejarah Pendidikan Teknik dan Kejuruan di Indonesia, Depdiknas.

[3] Raelin, J. A. (2008). Work-based learning. Bridging knowledge an action ini the workplace. New and revised Edition. San Francisco : John Wiley and Sons.

[4] Reeves Jenny, (2010), Professional Learning as Relational Practice, Springer Science+Business Media B.V.

[5] Indra Djati,(2008) Upaya SMK Menciptakan Lulusan Siap Kerja pelitapascasarjana.blogspot.com/.../upaya-smk-mencitakan-lulusan-siap... Rabu, 26 November 2008.

[6] Sudiyatno (2010). Pengembangan Model Penilaian Komprehensif Unjuk Kerja Siswa padaPembelajaran Berbasis Standar Kompetensi di SMK Teknologi Industri. Disertasi. Yogyakarta: Program Pascasarjana Universitas Negeri Yogyakarta 